\title{
FRAMING PEMBERITAAN KASUS KPK VS POLRI DI SURAT KABAR TRIBUN TIMUR
}

\section{Framing Projectors Case KPK Vs Polri In Tribun Timur Newspapers}

\author{
${ }^{1}$ Muhammad Aslam, ${ }^{2}$ Hasrullah, ${ }^{3}$ Tuti Bahfiarti \\ ${ }^{1}$ Jurusan Ilmu Komunikasi, Fakultas Ilmu Sosial dan Ilmu Politik, \\ Universitas Hasanuddin, Makassar (aslam.madridista@gmail.com) \\ ${ }^{2}$ Jurusan Ilmu Politik, Fakultas Ilmu Sosial dan Ilmu Politik, \\ Universitas Hasanuddin, Makassar (has_ullah@yahoo.com) \\ ${ }^{3}$ Jurusan Ilmu Komunikasi, Fakultas Ilmu Sosial dan Ilmu Politik, \\ Universitas Hasanuddin, Makassar (tutibahfiarti@yahoo.com)
}

\begin{abstract}
Abstrak
Penelitian ini bertujuan untuk 1) Mengetahui menggambarkan, serta menganalisis sikap dan posisi media lokal dalam wacana polemik kasus KPK VS Polri, 2) Mengetahui aspek yang cenderung ditonjolkan harian Tribun Timur dalam memberitakan kasus KPK VS Polri. Objek penelitian ini koran lokal Sulawesi Selatan yakni Tribun Timur. Tipe penelitian peneliti mengarah pada penggunaan metode penelitian kualitatif. Ia bermaksud memberi makna atas fenomena secara holistik dan harus memerankan dirinya secara aktif dalam keseluruhan proses studi. Orientasi kerjanya melegitimasi pemikiran bahwa pendekatan penelitian ini adalah subjektif. Hasil penelitian menunjukkan bahwa Tribun Timur dalam pemberitaannya mengenai kasus KPK VS Polri mengkonstruksi adanya upaya balas dendam sebagai wujud egoisme lembaga tinggi negara. Secara garis besar dalam pemberitaannya, Tribun Timur mendelegitimasi Polri sebagai penyebab masalah. Tribun Timur dalam pemberitaannya cenderung melihat Kepolisian Republik Indonesia ke arah yang negatif. Namun Tribun Timur tetap menjunjung prinsip cover both sides dengan menghimpun keterangan dari kedua belah pihak.
\end{abstract}

Kata kunci : Analisis Framing, KPK dan Polri, Tribun Timur.

\begin{abstract}
This study aims to 1) Knowing describe and analyze the attitude and position of the local media in the discourse of KPK VS Polri, 2) Knowing aspects tend to enjoy Tribun Timur in a case in which KPK VS Polri. The object of this study local newspaper in South East Sulawesi Tribun Timur. Type of research studies leading to the use of qualitative research methods. He intends to give meaning to the phenomenon in a holistic manner and should portray himself actively in the whole process of study. Orientation works legitimize the idea that this is a subjective approach to research. The results showed that the Tribun Timur in reporting on the case of KPK VS Polri construct their retaliation as a form of egoism high state institution. Broadly speaking, in its message, Tribun Timur delegitimize the Police as the cause of the problem. Tribun Timur in reporting are likely to see Polri negative direction. But the Tribun Timur uphold the principle of covering both sides to gather information from both parties.
\end{abstract}

Keywords: Framing Analysis, the Commission and the Police, Tribun Timur.

\section{PENDAHULUAN}

Media massa, khususnya dalam pemberitaannya media cetak, bertujuan membuat sebuah konstruksi atau susunan dari realitas yang ada. Realitas berarti yang mempunyai wujud, aktual (Komunika LIPI, 2007). Dalam hal ini pemberitaan upaya penangkapan penyidik KPK Novel Baswedan oleh Polri adalah realitas tersebut, mempunyai wujud yang berupa sebuah berita yang dituliskan di atas kertas oleh media cetak.

Realitas upaya penangkapan Novel Baswedan oleh Polri, cakupannya masih luas. Informasi yang terdapat dalam realitas tersebut cukup banyak, sehingga media cetak harus memilah sesuai dengan angle yang akan diangkat. Media cetak mengumpulkan dan memverifikasi fakta-fakta tersebut, kemudian 
dikonstruksi menjadi sebuah realitas baru. Realitas yang dimaksud adalah isu mengenai pelemahan KPK oleh Polri, di mana perbuatan yang dilakukan oleh lembaga penegak hukum di Indonesia tersebut adalah sebuah tindakan yang ingin melemahkan lembaga independen (KPK) yang menimbulkan citra negatif untuk Polri sendiri. Media melakukan pemberitaan sesuai dengan fakta yang ada, sehingga mereka harus menyusun pemberitaan tersebut dengan baik dan terencana.

Novel Baswedan, menurut KPK, adalah penyidik terbaik yang mereka miliki. Novel dinilai memiliki prestasi yang gemilang di KPK karena kinerjanya dalam menangani kasus-kasus korupsi skala besar, seperti suap wisma atlet dan suap Bupati Buol, seperti tercatat dalam Tribun Timur, Selasa 9 Oktober 2012.

Upaya penangkapan terhadap Novel Baswedan oleh Polri termasuk ke dalam upaya pelemahan KPK secara sistematis, seperti yang diungkapkan ketua KPK Abraham Samad. Sebelumnya, sudah ada upaya pelemahan dengan melakukan teror terhadap penyidik KPK. Puncaknya adalah upaya penangkapan terhadap Novel Baswedan tersebut.

Isu upaya pelemahan KPK oleh Polri ini berhembus sejak muncul istilah Cicak Vs. Buaya tahun 2009, yang dipopulerkan oleh Susno Duadji, yang pada saat itu menjabat sebagai Kabareskrim . Kasusnya adalah mengenai bocornya penyadapan terhadap dugaan kasus penyuapan nasabah Bank Century. Dalam penyadapan tersebut, nomor Susno ikut tersadap karena berhubungan dengan pihak nasabah Bank Century .

Dalam Cicak Vs. Buaya Jilid I ini juga terdapat kasus penetapan Bibit Samat Rianto dan Chandra M Hamzah (kasus Bibit dan Chandra) sebagai tersangka pada 7 Agustus 2009 karena adanya tindak pidana penyalahgunaan wewenang yang dilakukan keduanya yang melanggar Pasal 21 Ayat 5 UU No. 30 Tahun 2002 tentang KPK . Mereka diduga menerima uang dari Anggodo Widjojo, adik buron kasus Sistem Radio Radio Terpadu (SKRT). Kasus ini akhirnya berujung pada deponering atau penghentian perkara demi kepentingan umum .

Cicak adalah istilah yang mewakili KPK, sedangkan Buaya adalah istilah untuk Polri. Kemunculan istilah tersebut juga seakan menunjukkan konflik antara KPK dan Polri sulit untuk diredakan, padahal seharusnya kedua lembaga ini dapat saling membantu untuk menyelesaikan tugasnya. Upaya penangkapan terhadap Novel dan kasus KPKPolri lainnya, menurut pakar kepolisian Bambang Widodo Umar, dapat berpotensi munculnya Cicak Vs. Buaya Jilid II.

Dukungan dari masyarakat pun kembali muncul, setelah Cicak Vs. Buaya Jilid I juga menuai banyak dukungan masyarakat untuk KPK. Selain mendukung KPK untuk selalu memberantas korupsi, masyarakat juga ingin Presiden Susilo Bambang Yudhoyono, dapat menengahi polemik Kepolisian Republik Indonesia dan Komisi Pemberantasan Korupsi. Peran Presiden dalam hal ini adalah penting karena kepolisian berada di bawah wewenang Presiden. Tanggal 8 Oktober 2012, Presiden akhirnya menyikapi masalah tersebut dengan memberikan pidato yang dibuatnya sendiri. Sikap tegas Presiden dalam pidato tersebut mengundang kekaguman dari banyak kalangan dan masyarakat.

Salah satu bukti nyata tindak lanjut dari solusi yang diberikan Presiden pada pidatonya tersebut adalah mengenai waktu penugasan penyidik Polri yang bertugas di KPK. Presiden mengeluarkan Peraturan Pemerintah (PP) Nomor 103 Tahun 2012 sebagai revisi terhadap PP Nomor 63 Tahun 2005. PP tentang Sistem Manajemen Sumber Daya Manusia (SDM) KPK itu ditandatangani Presiden pada 7 Desember 2012. Peraturan ini hanya merubah ketentuan mengenai Pegawai KPK. Hanya tiga pasal yang direvisi, yakni Pasal 5 (penambahan Pasal 5A), ketentuan menyangkut sistem manajemen SDM KPK melalui perubahan Pasal 15, dan ketentuan tentang Tim Penasihat KPK melalui perubahan Pasal 24.

Penangkapan penyidik KPK Novel Baswedan oleh Polri sempat menghiasi wajahwajah surat kabar di Indonesia selama beberapa hari. Peristiwa ini menjadi berita utama, dilengkapi dengan gambar-gambar suasana saat itu di KPK dan grafis yang menunjukkan kronologi cerita. Surat kabar termasuk ke dalam media massa, jenis media massa cetak.

Pemberitaan KPK VS Polri ini telah menyedot banyak perhatian publik. Hal ini disebabkan kasus ini menyeret dua institusi besar di negeri ini. Selain itu, keberadaan Abraham Samad sebagai ketua KPK pada saat itu membuat kasus ini semakin menarik bagi media lokal seperti Tribun Timur. 
Hal-hal yang telah dipaparkan diatas membuat peneliti tertarik untuk melakukan sebuah penelitian. Peneliti tertarik untuk melihat bagaimana harian Tribun Timur mengkonstruksi realitas mengenai KPK VS POLRI sehingga peneliti mengangkat judul Analisis Framing Pemberitaan KPK VS Polri di Surat Kabar Tribun Timur

\section{BAHAN DAN METODE}

Tipe penelitian yang akan dilakukan ialah interpretatif dengan menggunakan pendekatan kualitatif. Penelititan ini digunakan untuk menggambarkan aspek tertentu dari sebuah realitas yang dibingkai oleh Tribun Timur menjadi sebuah berita yang kemudian menjadi realitas media dalam hal ini pemberitaan mengenai perseteruan KPK dan Polri.

Penelitian ini menggunakan pendekatan permasalahan dengan analisis framing dengan model Entman, Entman mengemukakan bahwa framing melibatkan 'seleksi' (selection) dan 'penonjolan' (salience). Framing model

Entman mendefinisikan persoalanpersoalan, mendiagnosa penyebab, membuat penilaian moral, dan menyarankan perbaikanperbaikan. Frame menggunakan textual devices seperti kata-kata tertentu, frase-frase tertentu, membuat referensi konstektual tertentu, memilih gambar-gambar atua film tertentu, memberikan contoh-contoh yang tipikal, atau merujuk pada sumber tertentu.

\section{Lokasi dan Rancangan Penelitian}

Penelitian ini dilaksanakan di Kota Makassar Ibukota Provinsi Sulawesi Tengah. Penetapan lokasi ini berdasarkan pada pertimbangan bahwa sasaran dari objek penelitian ini berdomisili di Kota Makassar

\section{Sumber Data}

Dalam penelitian ini pengumpulan sumber data yang dianggap relevan dengan objek penelitian.Data Primer dalam penulisan ini adalah berita perseteruan KPK dan Polri di dalam surat kabar Tribun Timur pada tanggal 13 Februari 2015 sampai 3 Mei 2015. Data Sekunder yang digunakan dalam penulisan ini adalah data-data yang diperoleh dari metode dokumentasi berupa penelitian kepustakaan (Library Research), yakni mengkaji informasi yang terdapat dalam berbagai literature, serta yang di download dari situs-situs internet (website),jurnal-jurnal online universitas di Indonesia, serta buku-buku yang berkaitan dalam penulisan ini

\section{Teknik Pengumpulan Data}

Pengumpulan data dilakukan dalam dua tahap, pertama observasi (pengamatan) surat kabar tersebut dan kedua memilih berita sesuai tanggal dan bulan pemuatan sesuai dengan batasan waktu pemuatan data yang telah peneliti tetapkan

\section{HASIL PENELITIAN}

Kasus KPK VS Polri ini menyedot perhatian sejumlah media di tanah air. Dalam skala media cetak, hal ini dibuktikan dengan seringnya kasus ini menjadi pemberitaan. Dalam lingkup lokal Sulawesi Selatan hingga Makassar pun, hal ini ikut menyita perhatian di beberapa media lokal. Hal yang menjadi faktor penunjang dari intensitas pemberitaan yang tinggi adalah keberadaan Abraham Samad yang merupakan putra daerah Sulawesi Selatan yang dijadikan tersangka oleh Polri.

Salah satu media lokal yang rutin memberitakan kasus ini adalah Tribun Timur. Tribun Timur kerap menempatkan pemberitaan kasus KPK VS Polri ini pada headline surat kabar. Tribun Timur memasukkan pemberitaan ini di headline pada saat muncul kabar terbaru tentang kasus tersebut. Pemberitaan yang dilakukan Tribun Timur dalam hal ini cenderung keras dan provokatif. Selain headline, Tribun Timur sering pula menempatkan kasus tersebut pada rubrik Tribun Nasional maupun rubrik Liputan Khusus. Pemberitaan pada kedua rubrik tersebut cenderung lebih banyak dengan pembahasan yang lebih mendalam. Hal ini juga tidak bisa dilepaskan dengan faktor ekonomi yang melatarbelakangi. Pemberitaan kasus KPK VS Polri dianggap sangat membantu dalam meningkatkan jumlah oplah.

Kasus KPK VS Polri dalam pemberitannya di Harian Tribun Timur tidak hanya menampilkan teks berita. Tribun Timur juga kerap kali menampilkan grafik atau foto yang memperkuat pemberitaan.

Hal lain yang membuat pemberitaan kasus KPK VS Polri ini menjadi semakin menarik adalah terlibatnya dua lembaga tinggi 
negara di dalamnya yakni Komisi Pemberantasan Korupsi (KPK) dan Kepolisian Republik Indonesia (Polri).

Kasus KPK VS Polri bermula pada awal tahun 2015. Kasus ini dimulai dengan penetapan Budi Gunawan sebagai tersangka kasus rekening gendut beberapa saat setelah diumumkan sebagai Kapolri baru menggantikan Sutarman.

Polri membalas penetapan tersangka pimpinan mereka dengan aksi serupa. Mereka memulai kriminalisasi terhadap KPK. Abraham Samad menjadi Ketua KPK pertama yang dijadikan tersangka oleh Polri dalam kasus pemalsuan dokumen kependudukan. Pada edisi 20 Februari 2015 Tribun Timur mengangkat berita berjudul "Sahabat Abraham Janji Jemput di Bandara". Dalam berita ini dinyatakan Abraham Samad sebagi pahlawan dan merupan korban kriminalisasi yang dilakukan Polri.

"Penjemputan ini kepada pahlawan dan pejuang Anti Korupsi Indonesia yang jadi korban kriminalisasi dan pelemahan kelembagaan KPK ini dilakukan, untuk menyelamatkan perjuangan melawan korupsi."

"Ketua Ikadin Sulsel, Yusuf Haseng mengatakan bahwa pihaknya akan memberi bantuan hukum kepada Abraham sehubungan dengan ditetapkannya Abraham sebagai tersangka oleh Polda Sulselbar."

Setelah itu, berturut-turut, Bambang Widjojanto dan Novel Baswedan dijerat Polri sebagi tersangka dalam kasus berbeda. Pada edisi 26 Februari 2015 Tribun Timur mengangkat berita berjudul "Anak Buah BG Sidik BW". Dalam berita ini memuat keberatan pengacara Bambang Widjojanto terhadap keberadaan Victor Simanjuntak pada saat penangkapan Bambang. Widjojanto. Pasalnya Victor dinilai merupakan anak buah Budi Gunawan. Hal ini ditengarai dapat mengaburkan netralitas Polri dalam kasus yang menjerat Bambang. Berikut kutipannya:

"Wakil Kepala Polri Komisaris Jenderal Badrodin Haiti mengakui dirinya menandatangani surat keputusan Victor Simanjuntak, anak buah Kepala Lembaga Pendidikan dan Kepolisian komjen Budi Gunawan, menjadi penyidik dalam kasus Wakil Ketua Komisi Pemberantasan Korupsi (KPK) nonaktif Bambang Widjojanto."

"Pengacara BW mempermasalahkan keberadaan Victor saat penangkapan Bambang."
Pada edisi 4 Mei 2015 Tribun Timur memuat berita berjudul "Novel Yakin Kriminalisasi". Dalam berita ini Novel menganggap dirinya dikriminalisasi oleh Polri. Hal tersebut disebabkan oleh sejumlah upaya paksa yang telah dilakukan kepolisian meskipun belum melakukan pemeriksaan terhadap Novel

"Penyidik Komisi Pemberantasan Korupsi (KPK), Novel Baswedan, menilai tindakan yang dilakukan penyidik Direktorat Tindak Pidana Umum Bareskrim Polri terhadap dirinya merupakan bentuk kriminalisasi"

"Pasalnya, aparat kepolisian belum memeriksanya, tetapi telah melakukan sejumlah upaya paksa".

\section{PEMBAHASAN}

Tribun Timur dalam pemberitaannya mengenai kasus KPK VS Polri mengkonstruksi adanya upaya balas dendam sebagai wujud egoisme lembaga tinggi negara. Secara garis besar dalam pemberitaannya, Tribun Timur mendelegitimasi Polri sebagai penyebab masalah. Polemik yang terjadi tidak lain disebabkan oleh Kepolisian Republik Indonesia sendiri yang mulai mengkriminalisasi KPK. Sosok-sosok seperi Victor Simanjuntak, Budi Waseso, hingga Budi Gunawan dianggap ikut bertanggung jawab dalam mengkriminalisasi KPK. Oleh karena itu, Polri baik secara kelembagaan maupun individu-individu yang berada di dalamnya dianggap berperan besar dalam menambah panjang kekisruhan dalam kasus KPK VS Polri ini.

Tribun Timur dalam melakukan framing berita cenderung mengindikasi sikap dari perusahaan pers bersangkutan. Hal ini dapat dilihat dari proses pemilihan judul, lead, visual image, serta penempatan sebagai headline maupun paging. Dalam dunia jurnalistik, berita dan framing adalah dua hal yang tidak dapat dipisahkan bahkan satu sama lain tidak bisa berdiri sendiri. Sebab setiap peristiwa yang kemudian akan ditulis atau dibuat dalam suatu laporan kejadian, keberadaan sang penulislah yang paling berperan. Siapa yang akan dijadikan pahlawan dan siapa yang akan jadi penjahat dibentuk dari sudut pandang pers (framing).

Tribun Timur konsisten dengan ideologinya sebagai surat kabar nasionalis dan menjunjung 
tinggi asas serta nilai kemanusiaan. Tribun Timur yang mengusung slogan "Spirit Baru Makassar" berusaha meyakinkan pembacanya dalam mengedepankan sisi kemanusiaan keterbukaan, meninggalkan pengkotakan latar belakang suku, agama, ras dan golongan serta tidak berada di bawah pengaruh kepentingan pihak tertentu dalam memunculkan berbagai wacana terkait dengan kasus KPK VS Polri.

Tribun Timur cenderung menempatkan pemberitaan kasus KPK VS Polri ini pada halaman utama sebagai headline. Hal tersebut mengindikasikan Tribun Timur menaruh perhatian yang besar terhadap kasus ini sekaligus sebagai nilai jual dalam upaya meningkatkan oplah. Selain itu, Tribun Timur juga kerap kali menuliskan Indepth Reporting tentang kasus KPK VS Polri. Tulisan tersebut termuat dalam rubrik Tribun Nasional maupun Liputan Khusus.

Tribun Timur dalam pemberitaan kasus KPK VS Polri cenderung memberikan citra negatif terhadap Polri. Hal tersebut dapat dilihat dari beberapa judul dan isi berita yang dimuat oleh Tribun Timur. Pada edisi 23 Februari 2015 Tribun Timur mengangkat berita berjudul "Buwas Tak Selalu Bikin Waswas". Dalam berita ini sosok Budi Waseso yang mendapat sorotan tajam setelah penangkapan Bambang Widjojanto. Berikut kutipannya:

"Budi Waseso mendapat sorotan tajam ketika Wakil Ketua KPK Bambang Widjojanto ditangkap penyidik Bareskrim Polri."

"Pakar hukum tata negara Refly Harun termasuk yang bersuara lantang. Ia menuding Budi Waseso sebagai dalang penangkapan BW."

Pada edisi 23 April 2015 Tribun Timur mengangkat berita berjudul "Wakapolri 'Baru' di Mata Akademisi Makassar". Dalam berita ini pelantikan Budi Gunawan disebut sarat kontroversi terkait kasus hukum yang masih menderanya. Berikut kutipannya:

"Pelantikan ini menuai kontroversi. Profil Komjen BG yang jadi tersangka kasus rekening gendut, dan membuat perombakan di lembaga KPK, membuat sejumlah pihak pesimistis"

"Saya tidak yakin karena pelantikan tersebut masih kontroversi dengan kasus yang masih melilitnya, masyarakat akan menilai ini"

Pada edisi 23 Februari 2015 Tribun Timur mengangkat berita berjudul "Polisi Janji Tak Lagi Kriminalisasi KPK". Dalam berita ini memuat komentar Imam Prasodjo yang menyoal Bareskrim yang mentersangkakan orang

"Sosiolog UI Imam Prasodjo yang juga anggota tim 9 dalam pertemuannya di Rupatama Mabes Polri, Minggu (22/2) kerap menyindir Kabareskrim Komjen Pol Budi waseso soal mentersangkakan orang"

Untuk lebih mendukung aktualitas beritanya Tribun Timur banyak menggunakan kutipan sebagai dasar atau acuan berita. Sebagaimana dipahami, pemakaian kutipan dengan label lengkap, menyangkut kapasitas sumber, mempunyai nilai atau grid dan pengaruh tinggi.

Independen dan objektif merupakan dua kata kunci yang menjadi kiblat dan klaim setiap jurnalis di seluruh dunia. Dalam melaporkan sebuah peristiwa atau berita seirang jurnalis harus objektif dan laporan beritanya juga harus berdasarkan fakta, ini umumnya dilakukan dengan memberi pemisahan yang tegas antara fakta disatu sisi dengan opini di sisi lain.

Dalam pemberitaan dan pemaparan masalahnya Tribun Timur menerapkan konsep cover both sides. Walaupun pada beberapa berita Kompas terkesan menyudutkan Kepolisian Republik Indonesia, namun Tribun Timur tetap melibatkan pihak Kepolisian Republik Indonesia sebagai narasumber yang berperan dalam membela diri

\section{KESIMPULAN DAN SARAN}

Berdasarkan hasil penelitian dan pembahasan, maka dapat ditarik kesimpulan Tribun Timur dalam pemberitaannya mengenai kasus KPK VS Polri mengkonstruksi adanya upaya balas dendam sebagai wujud egoisme lembaga tinggi negara. Secara garis besar dalam pemberitaannya, Tribun Timur mendelegitimasi Polri sebagai penyebab masalah.. Tribun Timur dalam pemberitaannya cenderung melihat Kepolisian Republik Indonesia ke arah yang negatif. Namun Tribun Timur tetap menjunjung prinsip cover both sides dengan menghimpun keterangan dari kedua belah pihak. Dari hasil penelitian ini, penulis memperoleh beberapa hal penting yang diharapkan bisa menjadi masukan bagi khalayak dan harian Tribun Timur. Untuk kalangan akademisi diharapkan untuk terus membuka dan mengembangkan pendekatan analisis framing dalam menganalisis isi media. Untuk pengembangan keilmuan pada Jurusan Ilmu Komunikasi dalam hal ini penelitian 
tentang pemberitaan KPK VS Polri hendaknya pada penelitian selanjutnya bisa menggali lebih dalam lagi dengan pendekatan lain, misalnya menggunakan anlisis wacana. Bagi khalayak, dibutuhkan daya kritis dalam menseleksi setiap informasi yang dimuat dalam satu pemberitaan yang dikonstruksi oleh media. Karena realitas dalam media bukanlah realitas sebenarnya, fakta tersebut telah dikonstruksi oleh media.

\section{DAFTAR PUSTAKA}

Ardianto E. (2007). Komunikasi Massa (Suatu Pengantar). Bandung; Simbiosa Rekatama Media

Cangara H. (2003). Pengantar Ilmu Komunikasi. Jakarta. Raja Grafindo Persada.

Danim S (2002) Inovasi Pendidikan. Bandung: CV Pustaka Setia

Effendi O (2001). Ilmu Komunikasi Teori dan Praktek. Bandung. Remaja Rosda Karya.
, (2002). Ilmu Teori dan Filsafat Komunikasi. Bandung. Remaja Rosda Karya .

(2003). Teori dan Praktek Ilmu Komunikasi, Bandung. Remaja Rosda Karya.

Eriyanto. (2011). Analisis Isi. Jakarta: Kencana Prenada Media Group

, (2002). Analisis Framing. Yogyakarta; LKIS Pelangi Aksara

Komunika. (2007). Problem Komunikasi antara Aparat Polri dan Pengunjuk Rasa. Jakarta; LIPI 